\title{
Initiation of the Himalayan Orogen as an Early Paleozoic Thin-skinned Thrust Belt
}

G.E. Gehrels*, P.G. DeCelles, A. Martin, T.P. Ojha, and G. Pinhassi, Department of Geosciences, University of Arizona, Tucson, Arizona 85721, USA

B.N. Upreti, Department of Geology, Tri-Chandra Campus, Tribhuvan University, Kathmandu, Nepal

\section{ABSTRACT}

Research by many workers in various regions of the Himalaya, combined with our recent geologic and geochronologic studies in Nepal, indicate that fundamental aspects of the Himalayan orogen originated in an early Paleozoic thrust belt and are unrelated to Tertiary IndiaAsia collision. Manifestations of early Paleozoic tectonism include ductile deformation, regional moderate- to highgrade metamorphism, large-scale southvergent thrusting, crustal thickening and the generation of granitic crustal melts, uplift and erosion of garnet-grade rocks, and accumulation of thick sequences of synorogenic strata. Determining the relative contributions of early Paleozoic versus Tertiary tectonism constitutes a significant challenge in understanding the Himalayan orogen.

\section{INTRODUCTION}

The Himalayan orogen consists of five main tectonic assemblages that are juxtaposed along Tertiary faults of the Himalayan thrust belt (Fig. 1). To the south, and structurally lowest, are Tertiary foreland basin strata that record uplift and erosion of the Himalaya since India-Asia collision, approximately 55 million years ago (Hodges, 2000). These strata are overlain along the Main Boundary Thrust by strata of mainly Proterozoic age of the Lesser Himalaya, which accumulated along the northern margin of the Indian craton.

In lower elevation portions of the Himalaya, Lesser Himalayan rocks are overlain along the Mahabharat Thrust by crystalline thrust sheets. The thrust sheets consist mainly of Neoproterozoic to lower Paleozoic metamorphic rocks and Cambro-Ordovician granite bodies, which are depositionally overlain by Ordovician and younger strata.

*ggehrels@geo.arizona.edu
In higher portions of the Himalaya, Lesser Himalayan rocks are overlain along the Main Central Thrust by highgrade metamorphic rocks of the Greater Himalaya. In central Nepal this assemblage consists mainly of a lower unit of pelitic and psammitic schist (Formation I), a middle unit of calc-silicate gneiss and marble (Formation II), and an upper unit of Cambro-Ordovician augen gneiss (Formation III) (terminology from Colchen et al., 1986). Greater Himalayan assemblages are in turn overlain along the South Tibetan Detachment System by Tethyan strata of mainly Paleozoic and Mesozoic age. Tethyan units in central Nepal referred to here include Neoproterozoic-Cambrian(?) sandstone and shale of the Sanctuary Formation, Neoproterozoic, Cambrian, and perhaps Lower Ordovician carbonates of the Annapurna Yellow and Nilgiri formations, Ordovician sandstone of the North Face Quartzite, and Silurian-Devonian shale, limestone, and sandstone that belong to various units (Colchen et al., 1986).

Tertiary juxtaposition of these assemblages was accompanied by high-grade regional metamorphism, penetrative ductile deformation, crustal thickening that led to the generation of granitic crustal melts, and rapid uplift and erosion of the mountain belt (e.g., Gansser, 1964; LeFort, 1975, 1996; Harrison et

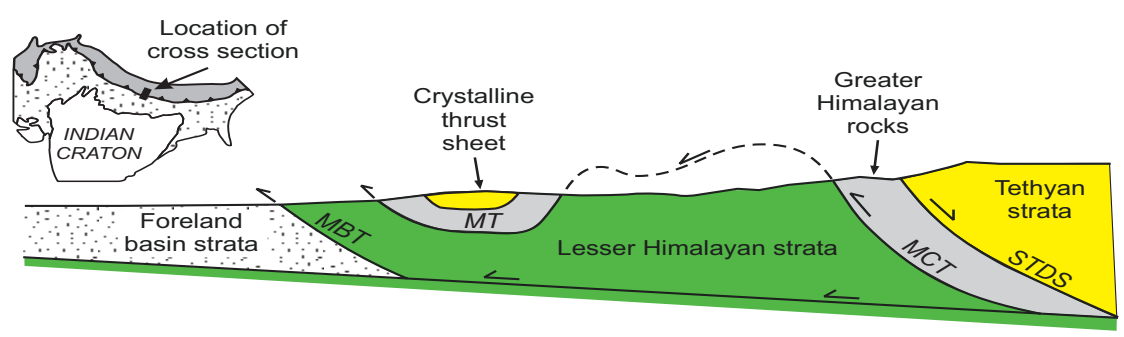

Figure 1. Schematic cross section through the Himalayan orogen at the longitude of central Nepal, showing the lithotectonic assemblages and faults referred to in the text (adapted from DeCelles et al., 2001). MBT_Main Boundary Thrust, MT—Mahabharat Thrust, MCT—Main Central Thrust, STDS—South Tibetan Detachment System. No vertical exaggeration. 


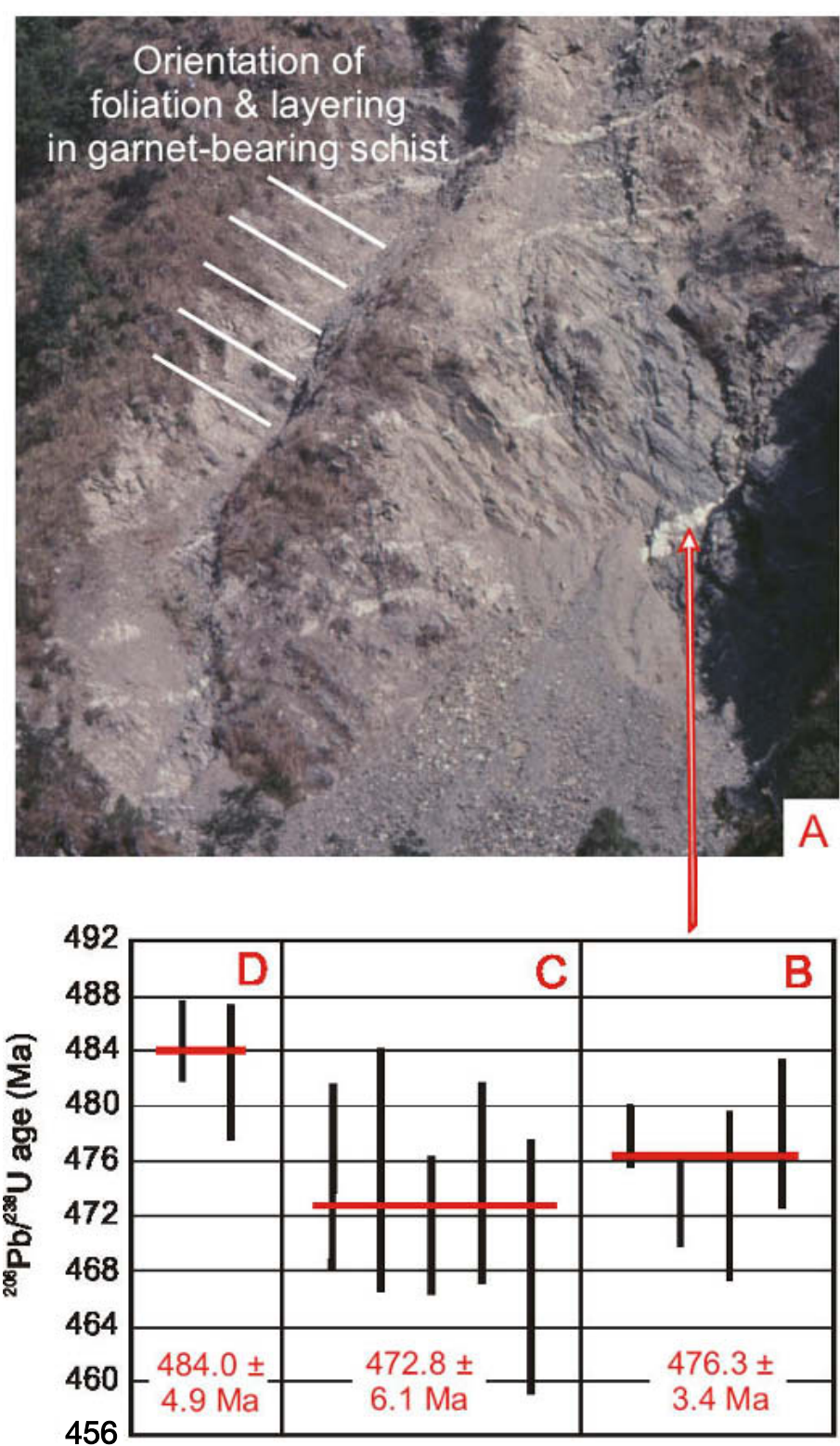

Figure 2. A: Exposure in the Kathmandu thrust sheet of non-deformed granitic dikes intruding across the foliation in garnet-bearing schist. B: ${ }^{206} \mathrm{~Pb} /{ }^{238} \mathrm{U}$ ages of four zircon grains from a non-deformed dike shown in Figure 2A, which places a minimum constraint on the age of ductile deformation in the region. The weighted mean age is $476.3 \pm 3.4 \mathrm{Ma}$. Location is near Bhimphedi (Lat $27^{\circ} 33.536^{\prime} \mathrm{N}$, Long $\left.85^{\circ} 07.766^{\prime} \mathrm{E}\right)$. C: ${ }^{206} \mathrm{~Pb} / 238 \mathrm{U}$ ages of five zircon grains from a non-deformed dike near the locality shown in Figure 2A (Mandu Khola: Lat $27^{\circ} 33^{\prime} 14.8^{\prime \prime} \mathrm{N}$, Long $85^{\circ} 06^{\prime} 16.2^{\prime \prime} \mathrm{E}$ ). The weighted mean of the five analyses is $472.8 \pm 6.1 \mathrm{Ma}$. $\mathbf{D}:{ }^{206} \mathrm{~Pb} /{ }^{238} \mathrm{U}$ ages of two zircon grains from foliated granite intruded by the non-foliated dike described in Figure 2C. The weighted mean age is $484.0 \pm 4.9 \mathrm{Ma}$. The latter two samples place a maximum age on at least some of the regional metamorphism and deformation of the schist. All analyses were conducted by laser-ablation inductively coupled plasma-mass spectrometry using a $25 \mu \mathrm{m}$ beam. Many additional analyses were conducted on zircon grains from each sample, but only the concordant analyses are shown. The error of each analysis is shown at $1 \sigma$, whereas the uncertainty of the weighted means is at $2 \sigma$. These errors include only uncertainties from the isotopic measurements; incorporation of systematic errors would add an additional 3\% error (at $2 \sigma$ level) to each age. that these granite bodies occur as tabular plutons emplaced along a regionally continuous north-dipping thrust that imbricates panels of schist overlain by marble. The foliation shown in Figure 2A occurs in the footwall of this thrust and is interpreted to be related to motion along the fault. The crosscutting relations described above accordingly indicate that at least some of the motion on this thrust fault occurred during Early Ordovician time.

2. Several lines of evidence indicate that rocks of the Greater Himalaya and the crystalline thrust sheets were regionally metamorphosed during early Paleozoic time. Stöcklin and Bhattarai (1977) and Stöcklin (1980) reported that the Palung and related Cambro-Ordovician granites in central Nepal were emplaced after regional garnet-grade metamorphism. Marquer et al. (2000) reported similar relations in the Greater Himalaya of northern India, where sillimanite- and kyanite-bearing schists were regionally folded prior to intrusion of the ca. 488 Ma Kinnaur Kailas granite. Early Paleozoic metamorphism in Greater Himalayan rocks has been dated directly in northern India at ca. $534 \mathrm{Ma}$ (Sm-Nd on garnet; Argles et al., 1999), in the northwest Himalaya at ca. $467 \mathrm{Ma}$ (Foster, 2000), in central Nepal at ca. $484 \mathrm{Ma}$ (U-Pb on monazite and zircon; Godin et al., 2001), and in eastern Nepal at ca. 436-548 Ma (Th-Pb on monazite; Catlos et al., 2002).

We have determined ${ }^{208} \mathrm{~Pb} /{ }^{232} \mathrm{Th}$ ages of monazite inclusions within garnet grains from 19 samples collected from the crystalline thrust sheets and the Greater Himalaya in Nepal. Figure 3 shows ages from a representative sample from the

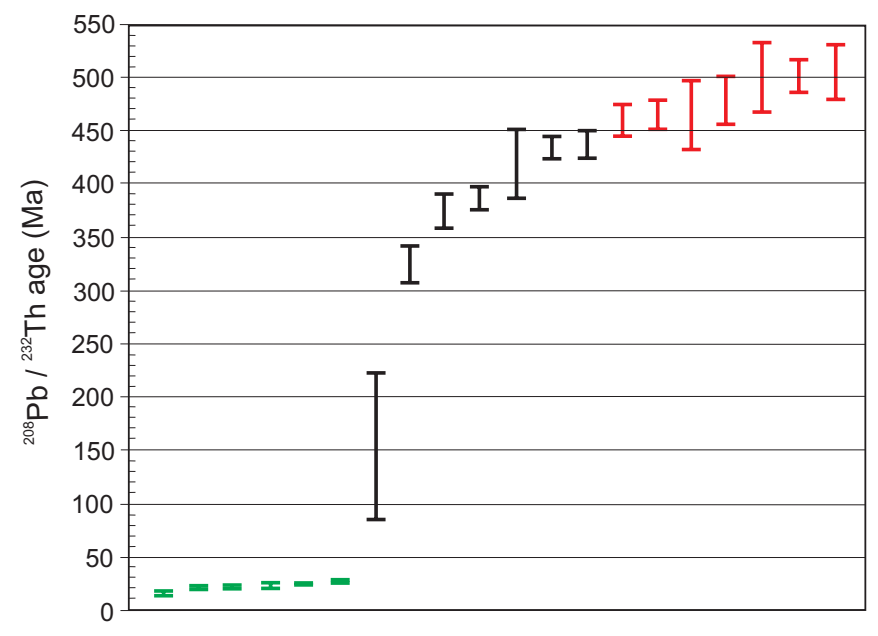

Figure 3. ${ }^{208} \mathrm{~Pb} / 232 \mathrm{Th}$ ages of monazite inclusions in garnet grains from kyanite-garnet-biotite schist of the Greater Himalaya (sample location along Marsyandi River in central Nepal, Lat $28^{\circ} 26.470^{\prime} \mathrm{N}$, Long $84^{\circ} 23.140^{\prime} \mathrm{E}$ ). The garnet crystals were extracted from a $1 \mathrm{~kg}$ sample, mounted in epoxy and sanded down to expose the central portions of most grains, and examined by scanning electron microscope to locate the monazite inclusions. Isotopic analyses were performed by laserablation inductively coupled plasma-mass spectrometry using an $8 \mu \mathrm{m}$ beam. The error bars for each analysis are at the $1 \sigma$ level, and do not include an additional $\sim 2 \%$ systematic error. Not shown is an additional age of $1283 \pm 80 \mathrm{Ma}$. We interpret the cluster of ages at 450-500 Ma (red symbols) to record early Paleozoic metamorphism and the cluster of ca. 20 Ma ages (green symbols) to record Tertiary metamorphism. Analyses of intermediate age (black symbols) may be from intergrowths of early Paleozoic and Tertiary monazite, or may record Pb loss in older monazites. 


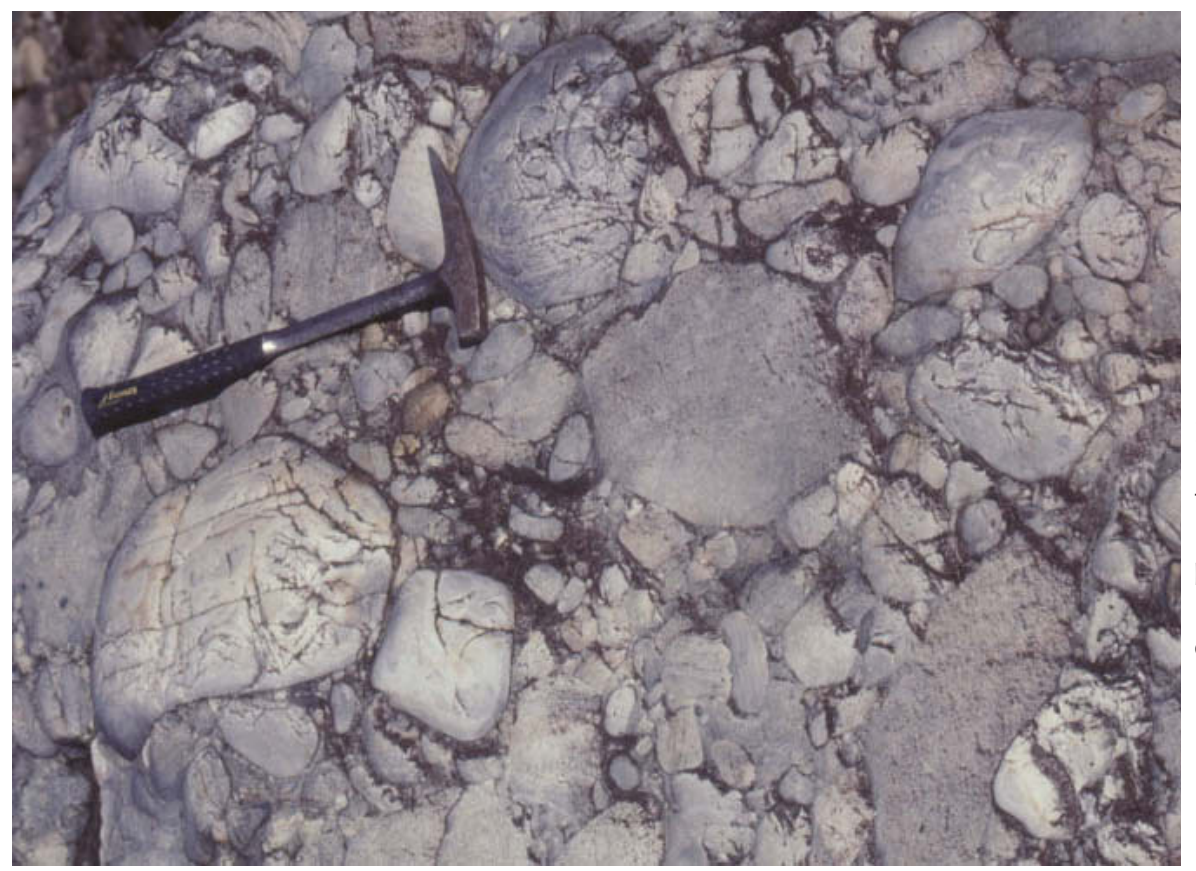

Figure 4. Ordovician(?) conglomerate from the lower Damgad Formation in far west Nepal. This conglomerate occurs in a layer $\sim 30 \mathrm{~m}$ in thickness along the base of the unit, and is best exposed in Korail Khola (Lat 29'17'59.8" $\mathrm{N}$, Long $\left.80^{\circ} 44^{\prime} 14.7^{\prime \prime} \mathrm{E}\right)$. Most clasts consist of quartzite, presumably derived from the underlying pre-Ordovician metamorphic rocks.

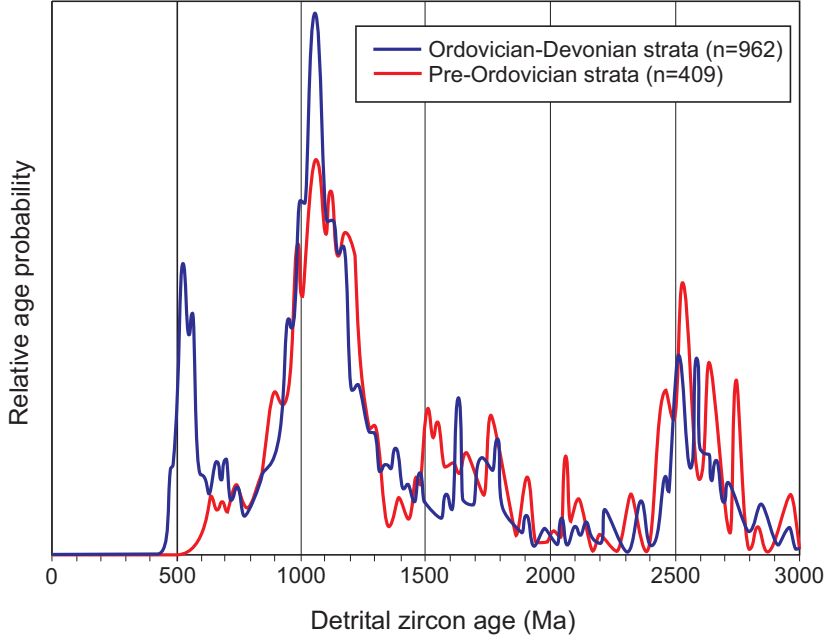

Figure 5. $\mathrm{Pb} / \mathrm{U}$ ages of single detrital zircon grains extracted from metasedimentary rocks of the Greater Himalaya and the crystalline thrust sheets (red curve) and from overlying Ordovician-Devonian sandstones of the Tethyan sequence and crystalline thrust sheets (blue curve). The age patterns indicate that the Ordovician-Devonian sandstones were derived mainly from underlying metasedimentary assemblages as well as from Cambro-Ordovician granite bodies. PreOrdovician samples were collected from Greater Himalayan rocks in central Nepal and from the Kathmandu and Dadeldhura thrust sheets. Younger samples were collected from the Ordovician Tistung Formation and the apparently correlative Chisapani Quartzite in the Kathmandu thrust sheet, from the Ordovician(?) Damgad Formation in far west Nepal (Dadeldhura thrust sheet), and from the North Face Quartzite (Ordovician) and Tilicho Pass Formation (Devonian) in the Tethyan sequence. Age information from several of these samples was reported previously by DeCelles et al. (2000). Each curve represents the sum of the probability distributions of all grains analyzed from each set of units, with ${ }^{206} \mathrm{~Pb} / 238 \mathrm{U}$ ages used for $<800 \mathrm{Ma}$ grains and ${ }^{206} \mathrm{~Pb} /{ }^{207} \mathrm{~Pb}$ ages used for $>800 \mathrm{Ma}$ grains. Analyses were performed by laser-ablation inductively coupled plasma-mass spectrometry, using a beam diameter ranging from 25 to $50 \mu \mathrm{m}$.
Greater Himalaya, with an additional age (not shown) of 1283 $\pm 80 \mathrm{Ma}$. The ages clearly document ca. $20 \mathrm{Ma}$ metamorphism (green error bars), but also record earlier phases of garnet growth. Our preliminary interpretation is that the ca. $1283 \mathrm{Ma}$ age records garnet growth in the source rock from which detritus in Greater Himalayan protoliths was shed, ages between 450 and $500 \mathrm{Ma}$ (red error bars) record early Paleozoic metamorphism, and the scattered ages between 150 and $450 \mathrm{Ma}$ (black error bars) are either intergrowths of Tertiary and early Paleozoic monazite in the same inclusion or a result of $\mathrm{Pb}$ loss in early Paleozoic monazites.

3. There is considerable stratigraphic evidence for early Paleozoic uplift and erosion in the Himalaya. In Tethyan strata of northern India (Zanskar area), a thick section of Middle Ordovician conglomerate rests on an angular unconformity and records erosion of a mountainous area dominated by sedimentary rocks (Garzanti et al., 1986). These strata are interpreted to have accumulated in the foreland basin of a thrust belt that was active during Late Cambrian(?) through Middle Ordovician time (Garzanti et al., 1986). The apparent cessation of early Paleozoic sedimentation on the northern Indian craton during Cambrian time may also record the onset of early Paleozoic tectonism (Brookfield, 1993; Valdiya, 1995).

Evidence for early Paleozoic uplift and erosion also exists in Nepal. In the crystalline thrust sheets, synorogenic sedimentation is recorded by the accumulation of conglomeratic and arkosic sandstone of Ordovician age (Stöcklin and Bhattarai, 1977; Kumar et al., 1978; Stöcklin, 1980). In the Kathmandu area, the basal conglomerate is a thin horizon that rests conformably on fine-grained marine strata in most areas (Stöcklin and Bhattarai, 1977; Stöcklin, 1980; Funakawa, 2001). In far west Nepal, however, the conglomeratic strata reach $30 \mathrm{~m}$ in thickness and contain clasts up to $40 \mathrm{~cm}$ in diameter (Fig. 4).

In the Tethyan sequence, a major change in sedimentation is recorded by a thick sequence of Neoproterozoic-CambrianLower Ordovician(?) carbonates overlain by $\sim 400 \mathrm{~m}$ to $\sim 560 \mathrm{~m}$ of Ordovician arkosic sandstone and siltstone (North Face 
A. Neoproterozoic, Cambrian, Early Ordovician(?)
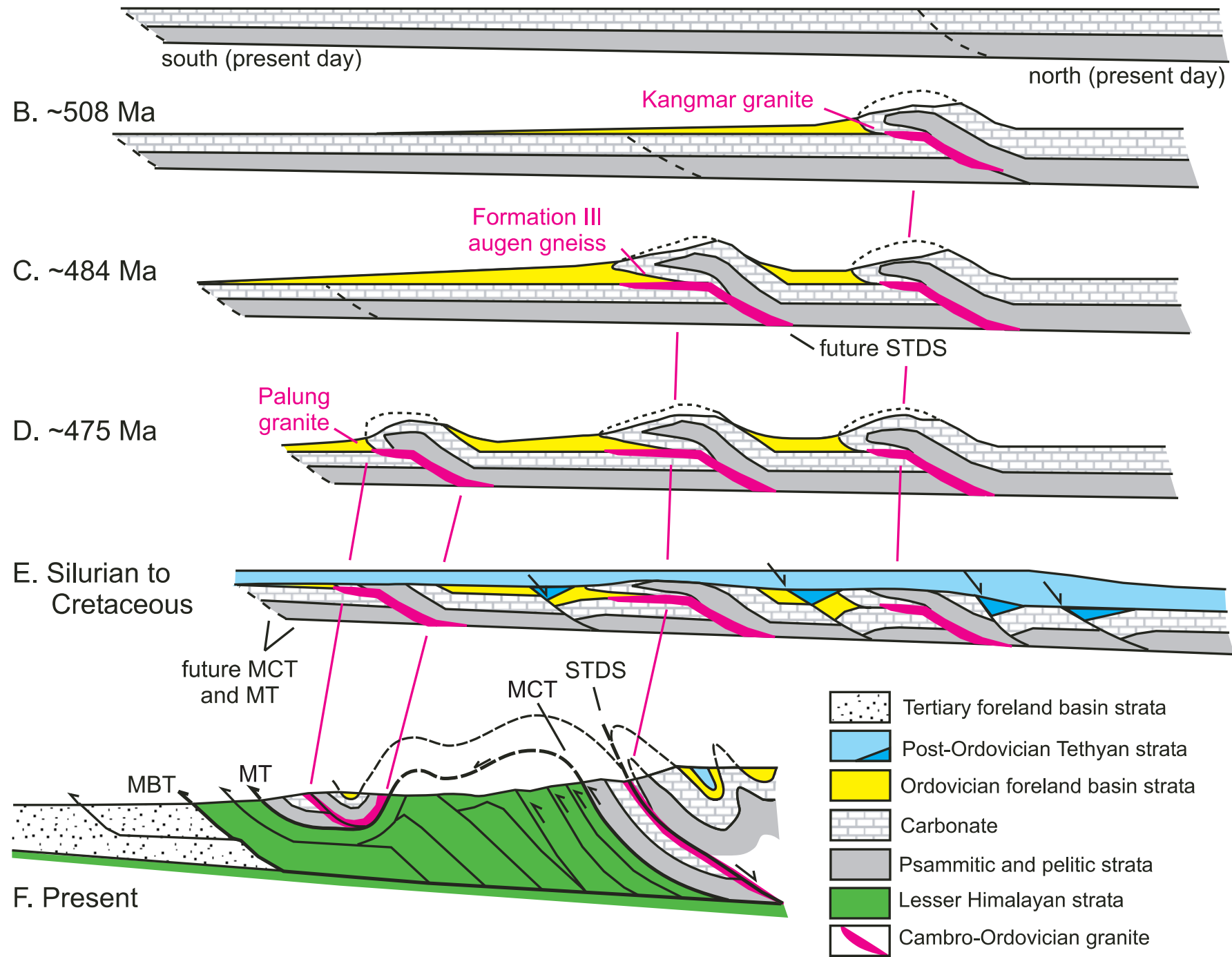

Figure 6. Proposed model for early Paleozoic tectonism in the Himalaya. Panel A shows the accumulation of Neoproterozoic, Cambrian, and possibly Lower Ordovician marine strata along or outboard of India's northern margin. Panels B-D show the interpreted progression of Late Cambrian(?) through Middle Ordovician thrusting, emplacement of granitic sills along the thrust faults, erosion of the orogen, and accumulation of synorogenic strata in a foreland basin setting. Panel E shows accumulation of Silurian to Cretaceous strata, and panel $\mathrm{F}$ shows the position of early Paleozoic rocks and structures in the present-day Himalaya. In F, the imbricated panels of psammitic and pelitic strata overlain by carbonate include the Raduwa Formation and Bhainsedobhan Marble overlain by the Kulikhani Formation and Markhu Marble in the Kathmandu thrust sheet, Formation I Formation II in the Greater Himalaya, and the Sanctuary Formation \Annapurna Yellow and Nilgiri Formations in the Tethyan zone. MBT—Main Boundary Thrust, MT—Mahabharat Thrust, MCT—Main Central Thrust, STDS—South Tibetan Detachment System.

Quartzite) followed by $1300 \mathrm{~m}$ of Silurian-Devonian shale, limestone, and micaceous and feldspathic sandstones (Bodenhausen et al., 1964; Bordet et al., 1971).

Detrital zircon ages indicate that the Ordovician-Devonian strata accumulated during uplift and erosion of the underlying metamorphic and plutonic rocks. Pre-Ordovician rocks in the crystalline thrust sheets and in the Greater Himalaya generally yield mainly 1.0-1.3 Ga detrital zircons, with subordinate populations of older grains (Fig.
5). The overlying Ordovician through Devonian strata yield very similar ages but also contain a significant proportion of grains with ages of 480-530 Ma. These young grains, combined with the arkosic composition of the host sandstones, most likely record uplift and erosion of the underlying CambroOrdovician granite bodies soon after their emplacement.

\section{PROPOSED MODEL}

We propose a model in which the deformation, metamorphism, pluto- nism, uplift, and erosion described above developed within a south-vergent thrust belt that was active during Late Cambrian(?)-Middle Ordovician time (Fig. 6). The first stage (Fig. 6A), during Neoproterozoic, Cambrian, and perhaps into Early Ordovician time, involves accumulation of marine pelitic and psammitic sediments overlain by a thick succession of carbonate rocks. These units apparently thickened northward, reaching at least $15 \mathrm{~km}$, and accumulated along or outboard of the northern margin of India. 
Beginning during Late Cambrian(?)Early Ordovician time, these strata were imbricated along north-dipping thrust faults, with displacements of $>10 \mathrm{~km}$ on at least some thrusts (Fig. 6B-6D). The southernmost thrust system recognized is in the Kathmandu thrust sheet (shown in Fig. 6D), as described above. We suggest that a similar thrust system developed farther to the north (in present coordinates) and is now preserved in higher portions of the Himalaya (Fig. 6C). The footwall of this thrust system consists of psammitic and pelitic schist (Formation I) overlain by calc-silicate gneiss and marble (Formation II) of the Greater Himalaya. These rocks are interpreted to be high-grade equivalents of Tethyan strata in the hangingwall of the thrust, which include the Sanctuary Formation overlain by the Annapurna Yellow and Nilgiri formations (following from LeFort's [1975] correlation of Formation II with the Annapurna Yellow Formation). Based on analogy with the Palung and related granites in the Kathmandu thrust sheet, the sill-like Cambro-Ordovician augen gneisses of Formation III are interpreted to have been emplaced along this early Paleozoic thrust (Fig. 6C). In contrast to the crystalline thrust sheets, however, the early Paleozoic thrust in the high Himalaya is interpreted to have been reactivated by normal motion along the South Tibetan Detachment System (Burchfiel et al., 1992), thereby offsetting upper portions of the CambroOrdovician plutons and dropping lower grade Tethyan strata down against their higher grade Greater Himalayan equivalents. We postulate that a similar thrust system may have existed farther to the north (in present coordinates) in association with the Kangmar granite (Fig. 6B).

The interpretation that the thrust belt propagated southward (Fig. 6B-6D) is based largely on the ages of the Cambro-Ordovician granite bodies, which apparently young to the south. Available ages are ca. $508 \mathrm{Ma}$ for the Kangmar Granite (Lee et al., 2000), ca. $484 \mathrm{Ma}$ for Formation III in the Greater Himalaya (Godin et al., 2001), and ca. 470-485 Ma for the Palung and related granite bodies in the Kathmandu thrust sheet (Schärer and Allègre, 1983; Johnson et al., 2001; Fig. 2). These granitoids may have been generated by crustal thickening during thrusting, and their occurrence along early Paleozoic thrust faults suggests that they may have played an active role in development of the thrust belt (e.g., Hollister and Crawford, 1986).

Crustal thickening within the thrust belt was apparently sufficient to generate garnet-grade metamorphism in the crystalline thrust sheets (Stöcklin, 1980) and kyanite- and sillimanite-grade metamorphism at least locally in Greater Himalayan rocks (Marquer et al., 2000; Godin et al., 2001). This raises the possibility that some of the pressure-temperature information recovered from Himalayan metamorphic assemblages may have little to do with India-Asia collision and offers an alternative explanation for the inverted metamorphism that is one of the hallmarks of the Himalayan orogen (Gansser, 1964; LeFort, 1975, 1996; Harrison et al., 1997; Hodges, 2000). Based on existing constraints, it is plausible that CambroOrdovician granitoids served as a heat source for sillimanite-grade metamorphism common in higher portions of the Greater Himalaya (Godin et al., 2001), whereas burial during Tertiary tectonism would have driven the kyanite-grade metamorphism that characterizes lower portions of the Greater Himalaya.

Following Garzanti et al. (1986), the Ordovician clastic strata are interpreted to have accumulated in a foreland basin setting as the thrust belt propagated southward (Fig. 6B-6D). Erosion was apparently of sufficient depth that the Cambro-Ordovician plutons contributed a significant proportion of the detritus in synorogenic Ordovician-Devonian strata (Fig. 5).

Following this early Paleozoic orogeny, the region was blanketed by strata of Silurian through Cretaceous age, which formed in a passive margin setting along India's northern margin (Fig. 6E). This was followed during Tertiary time by the deformation, metamorphism, uplift, and erosion resulting from India-Asia collision (Fig. 6F) that has been described by many workers (e.g., Gansser, 1964; LeFort, 1975, 1996; Harrison et al., 1997; Hodges, 2000; DeCelles et al., 2001).

\section{CONCLUSIONS}

Our model for early Paleozoic tectonism in the Himalaya is built on several different lines of evidence that derive from our recent field and geochronologic studies and the research of many previous workers (e.g., Gansser, 1964; Stöcklin and Bhattarai, 1977; Kumar et al., 1978; Stöcklin, 1980; Garzanti et al., 1986; Valdiya, 1995; Argles et al., 1999; Marquer et al., 2000; Foster, 2000; Godin et al., 2001; Catlos et al., 2002). Although the model provides a coherent framework for these observations, it also raises several fundamental questions concerning the evolution of the Himalayan orogen.

1. What were the conditions and patterns of early Paleozoic versus Tertiary deformation and metamorphism in the Himalaya? At present, there is evidence for high-grade metamorphism and regional ductile deformation during both episodes, but there are few constraints on their relative proportions. Additional information is needed to constrain the nature and origin of metamorphism and deformation during each orogenic phase and to test alternative explanations for features such as the inverted metamorphism in Greater Himalayan rocks.

2. What is the fundamental nature of the Main Central Thrust and Mahabharat Thrust, which now serve as the base of rocks that clearly record early Paleozoic tectonism? If the early Paleozoic orogen was constructed along India's northern margin, then the Main Central Thrust and Mahabharat Thrust have only experienced offset related to shortening in the Himalayan thrust belt. In contrast, if the orogen formed within the paleoTethys, outboard of the Indian craton (DeCelles et al., 2000), then the Main Central and Mahabharat Thrusts represent an accretionary suture with potentially much greater amounts of early Paleozoic and/or Tertiary displacement.

3. What was the extent of early Paleozoic uplift and erosion? Are garnetgrade rocks present in frontal regions of the Himalayan thrust belt due to largescale erosion during Tertiary motion on the Main Central Thrust and Mahabharat Thrust, or were these garnet-bearing schists originally brought to the surface during early Paleozoic time? Better constraints on the amounts of uplift and erosion during early Paleozoic and 
Tertiary time may have an important impact on our understanding of the linkage between weathering and erosion in the Himalayan orogen, climate change, and seawater chemistry (e.g., Edmond, 1992; Ruddiman, 1997).

Because of these profound uncertainties, the recognition of early Paleozoic tectonism raises many new questions about the history of the Himalayan orogen and its relations to India-Asia collision. Our model is offered as a means of stimulating research that will address these questions.

\section{ACKNOWLEDGMENTS}

We thank Jay Quade for encouraging Gehrels and DeCelles to become involved in Himalayan research and Sue Beck, Paul Kapp, Jay Quade, and George Zandt for helpful comments on the manuscript. Reviewed by L. Godin and P. Myrow. This research was supported by National Science Foundation Grant EAR-0105339.

\section{REFERENCES CITED}

Argles, T.W., Prince, C.I., Foster, G.L., and Vance, D. 1999, New garnets for old? Cautionary tales from young mountain belts: Earth and Planetary Science Letters, v. 172, p. 301-309.

Bodenhausen, J.W.A., De Booy, T., Egeler, C.G., and Nijhuis, H.J., 1964, On the geology of central-west Nepal-A preliminary note, Rep. 22nd International Geologic Congress, Delhi, XI, p. 101-122.

Bordet, P., Colchen, M., Krummenacher, D., LeFort, P., Mouterde, R., and Remy, M., 1971, Recherches geologiques dans I'Himalaya du Nepal, region de la Thakkhola: Paris, Centre National de la Recherche Scientifique, 279 p.

Brookfield, M.E., 1993, The Himalayan passive margin from Precambrian to Cretaceous times: Sedimentary Geology, v. 84 , p. $1-35$

Burchfiel, B.C., Chen, Z., Hodges, K.V., Liu, Y., Royden, L.H., Deng, C., and Xu, J., 1992, The south Tibetan detachment system, Himalayan orogen: Extension contemporane- ous with and parallel to shortening in a collisional mountain belt: Boulder, Colorado, Geological Society of America Special Paper 269, $41 \mathrm{p}$

Catlos, E.J., Harrison, T.N., Manning, C.E., Grove, M., Rai, S.M., Hubbard, M.S., and Upreti, B.N., 2002, Records of the evolution of the Himalayan orogen from in situ Th- $\mathrm{Pb}$ ion microprobe dating of monazite: Eastern Nepal and western Garhwal: Journal of Asian Earth Sciences, v. 20, p. 459-479.

Colchen, M., LeFort, P., and Pêcher, A., 1986, Annapurna, Manaslu, Ganesh Himal: Paris, Centre National de la Recherche Scientifique, $136 \mathrm{p}$.

DeCelles, P.G., Gehrels, G.E., Quade, J., Lareau, B., and Spurlin, M., 2000, Tectonic implications of U-Pb zircon age of the Himalayan orogenic belt in Nepal: Science, v. 288, p. 497-499.

DeCelles, P.G., Robinson, D.M., Quade, J., Ojha, T.P., Garzione, C.N., Copeland, P., and Upreti, B.N., 2001 Stratigraphy, structure, and tectonic evolution of the Himalayan fold-thrust belt in western Nepal: Tectonics, v. 20 , p. $487-509$.

Edmond, J.M., 1992, Himalayan tectonics, weathering processes, and the strontium isotope record in marine limestones: Science, v. 258, p. 1594-1597.

Foster, G.L., 2000, The pre-Neogene thermal history of the Nanga Parbat Haramosh Massif and the NW Himalaya [Ph.D. dissertation]: The Open University, United Kingdom, $345 \mathrm{p}$

Funakawa, S., 2001, Lower Paleozoic Tethys sediments from the Kathmandu nappe, Phulchauki area, central Nepal: Journal of Nepal Geological Society, v. 25, p. 123-134.

Gansser, A., 1964, Geology of the Himalayas: London, Wiley Interscience, $289 \mathrm{p}$.

Garzanti, E., Casnedi, R., and Jadoul, F., 1986, Sedimentary evidence of a Cambro-Ordovician orogenic event in the northwestern Himalaya: Sedimentary Geology, v. 48, p. 237-265.

Godin, L., Parrish, R.R., Brown, R.L., and Hodges, K.V., 2001, Crustal thickening leading to exhumation of the Himalayan metamorphic core of central Nepal: Insight from $\mathrm{U}-\mathrm{Pb}$ geochronology and ${ }^{40} \mathrm{Ar} /{ }^{\beta 9} \mathrm{Ar}$ thermochronology: Tectonics, v. 20, p. 729-747

Harrison, T.M., Ryerson, F.J., LeFort, P., Yin, A., Lovera, O., and Catlos, E.J., 1997, A late Miocene-Pliocene origin for the central Himalayan inverted metamorphism: Earth and Planetary Science Letters, v. 146, p. E1-E7.

Hodges, K.V., 2000, Tectonics of the Himalaya and southern Tibet from two perspectives: Geological Society of America Bulletin, v. 112, p. 324-350.

Hollister, L.S., and Crawford, M.L., 1986, Melt-enhanced deformation: A major tectonic process: Geology, v. 14, p. 558-561.

Johnson, M.R.W., Oliver, G.J.H., Parrish, R.R., and Johnson, S.P., 2001, Synthrusting metamorphism, cooling, and erosion of the Himalayan Kathmandu complex, Nepal: Tectonics, v. 20, p. 394-415.

Kumar, R., Shah, A.N., and Bingham, D.K., 1978, Positive evidence of a Precambrian tectonic phase in central Nepal Himalaya: Journal of the Geological Society of India, v. 19, p. 519-522.

Lee, J., Hacker, B.R., Dinklage, W.S., Wang, Y., Gans, P., Calvert, A., Wan, J., Chen, W., Blythe, A.E., and McClelland, W., 2000, Evolution of the Kangmar dome, southern Tibet: Structural, petrologic, and thermochronologic constraints: Tectonics, v. 19, p. 872-895.

LeFort, P., 1975, Himalayas: the collided range; Present knowledge of the continental arc: American Journal of Science, v. 275-A, p. 1-44.

LeFort, P., 1996, Evolution of the Himalaya, in Yin, A., and Harrison, T.M., eds., The tectonic evolution of Asia: Cambridge, Cambridge University Press, p. 95-109.

LeFort, P., Debon, F, and Sonet, J., 1983, The Lower Paleozoic "Lesser Himalayan" granitic belt: Emphasis on the Simchar pluton of central Nepal, in Shams, F.A., ed., Granites of the Himalayas, Karakorum, and Hindu Kush: Lahore, Punjab University, p. 235-255.

Marquer, D., Chawla, H.S., and Challandes, N., 2000, PreAlpine high-grade metamorphism in the High Himalaya crystalline sequences: Evidence from Lower Palaeozoic Kinnaur Kailas granite and surrounding rocks in Sutlej Valley (Himal Ptadesch, India): Eclogae Geologicae Helvetiae, v. 93 , p. $207-220$

Ruddiman, W.F., editor, 1997, Tectonic uplift and climate change: New York, Plenum Press, 535 p.

Schärer, U., and Allègre, C.J., 1983, The Palung granite (Himalaya): High-resolution U-Pb systematics in zircon and monazite: Earth and Planetary Science Letters, v. 63, p. 423-432.

Stöcklin, J., 1980, Geology of Nepal and its regional frame: Geological Society [London] Journal, v. 137, p. 1-34.

Stöcklin, J., and Bhattarai, K.D., 1977, Geology of the Kathmandu area and central Mahabharat Range, Nepal: Nepal Department of Mines and Geology, Himalayan Report, $86 \mathrm{p}$.

Thakur, V.C., 1992, Geology of the western Himalaya: Oxford, Pergammon Press, 363 p.

Valdiya, K.S., 1995, Proterozoic sedimentation and Pan-African geodynamic development of the Himalaya: Precambrian Research, v. 74, p. 35-55.

Manuscript submitted March 18, 2003; accepted June 20, 2003. 